\title{
Old forest edges may promote the distribution of forest species in carabid assemblages (Coleoptera: Carabidae) in Croatian forests
}

\author{
AndReJa BRIGIĆ ${ }^{1}$, Marija STARČEVIĆ ${ }^{2}$, Boris HRAŠOVEC ${ }^{3}$ and Zoltán ELEK ${ }^{4}$ \\ ${ }^{1}$ Department of Zoology, Faculty of Science, University of Zagreb, Rooseveltov trg 6, 10000 Zagreb, Croatia; \\ e-mail: andreja.brigic@biol.pmf.hr \\ ${ }^{2}$ Ante Kovačića 7, 47000 Karlovac, Croatia; e-mail: marijastarcevic.eb@gmail.com \\ ${ }^{3}$ Department of Forest Protection and Wildlife Management, Faculty of Forestry, University of Zagreb, Svetošimunska 25, \\ 10002 Zagreb, Croatia; e-mail: hrasovec@sumfak.hr \\ ${ }^{4}$ MTA-ELTE-MTM Ecology Research Group, Hungarian Academy of Sciences, c/o Biological Institute of Eötvös Loránd University, \\ Budapest, Pázmány Péter sétány 1/C., H-1117 Budapest, Hungary and Hungarian Natural History Museum, Baross u. 13., Budapest, \\ H-1088, Hungary; e-mail: zoltan.elek2@gmail.com
}

Key words. Coleoptera, Carabidae, ecotone, ground beetles, beech-fir forests, Croatia

\begin{abstract}
Boundaries between habitats are usually accompanied by transitions in the diversity and structural complexity of insect assemblages. Edge effects on carabid beetle assemblages across forest-meadow ecotones in Dinaric beech-fir forests were determined in the Gorski Kotar region of western Croatia. Carabid beetles were sampled using pitfall traps set along gradients extending $60 \mathrm{~m}$ from the forest edge into its interior and $60 \mathrm{~m}$ into the meadow. Embedded forest edges were greater than 100 years old and had a similar composition and structure of vegetation to that in the adjacent forest. A total of 20,526 individuals belonging to 66 carabid beetle species were recorded. Carabid assemblages in the ecotones were more similar to those in the forest interiors than those in the meadows. The classical edge effect hypothesis was not supported, since the ecotones were less diverse than the meadows, while the carabid assemblages of the forest interiors were the least diverse. Soil temperature, soil humidity and light intensity did not differ significantly between the ecotones and the forest interior. Therefore, embedded forest edges reduced the microclimate edge effect by providing stable microclimatic conditions for carabid assemblages similar to those in the forest interior. In addition, this enabled forest specialists and generalists to occur right up to the forest edge and maintain stable populations in the ecotone. On the other hand, ecotones acted as filters for certain forest generalist species and true barriers for most open-habitat species. This study confirmed that the structure and ages of the vegetation at edges may play a key role in determining the spatial pattern of carabid beetles across forest-meadow ecotones.
\end{abstract}

\section{INTRODUCTION}

Dinaric beech-fir forests are characterized by a natural composition and structure of vegetation and cover approximately 150,000 ha in the Dinaric Mountains in Croatia (Vukelić, 2012). They are managed using uneven-aged silviculture practices, which result in forest stands composed of trees of different ages and sizes growing together in the same area (Boncina, 2011). Consequently, regeneration in these forests is a permanent and ongoing process (Vukelić et al., 2008). Multilayered continuous forest cover provides favourable microclimatic conditions for ground-dwelling invertebrates and prevents soil erosion (Thiele, 1977; Vukelić et al., 2008). The biodiversity value of Dinaric beech-fir forests is high since they host many endemic and relict plant species (Horvat et al., 1974) and support high animal diversity (e.g. Rucner, 1994; Vujčić-Karlo, 1999; Štrbenac et al., 2008). These Dinaric beech-fir forests have been subjected to centuries of sporadic anthropogenic activities, which may also have contributed to their high conservation value and the development of the contrasting boundaries between forest and open habitats such as fallows or hay meadows (Klepac, 2001). These habitat edges are usually connected with a large forest matrix area and may play a crucial role in the preservation of biological diversity, especially of grassland biota (Mihoci et al., 2006; Topić \& Vukelić, 2009).

Forest edges are usually defined as a type of ecotone, a transitional zone between adjacent habitats characterized by a unique physical appearance, manifested in changes in the physical and biological conditions, space and time scales and the strength of the interactions between adjacent habitat matrices (Holland, 1988; Gosz, 1991; Murcia, 1995; Lindenmayer \& Fischer, 2006). The abiotic component of habitat edges might be affected by microclimate due to marked changes in light intensity, air temperature, relative humidity and soil moisture (Saunders et al., 1991; Murcia, 1995; Risser, 1995; Kapos et al., 1997), while the biotic component of edges includes changes in predation, parasitism and species interactions (Andrén, 1992; Robinson et al., 1995; Lahti, 2001). Such changes can have profound effects on species distribution and diversity, assemblage dynamics and overall ecosystem functioning (Murcia, 1995; Ewers \& Didham, 2006; Laurance et al., 2007; Watling \& Orrock, 2010).

The intensity of edge effects might be context-specific and modulated by several factors, such as age, edge physiognomy and contrast between adjacent types of matrix (Matlack, 1994; Kolasa \& Zalewski, 1995; Ries et al., 
2004). The structure and composition of vegetation strongly affects edge effects and animal movements (Gosz, 1991; Matlack, 1994; Cadenasso et al., 2003). Therefore, edges may act as barriers or filters by inhibiting or enhancing movements of animal species (Forman \& Moore, 1992; Lidicker, 1999). Edge permeability (i.e. migration through the edge) is more intensive at recent and abrupt forest edges than at the edges of old forests, due to the physical similarities between old forests and their edges. Hence, this may mitigate the filtering function of old forest edges (Matlack, 1994).

The classic edge effect hypothesis emphasises that ecotones are habitats of enhanced diversity and productivity compared to adjacent matrix habitats (Clements, 1905; Leopold, 1933). Several studies have shown that forest edges promote higher species richness, diversity and abundance in comparison to adjacent matrix habitats of various animal taxa, e.g. small mammals (Pardini, 2004), ungulates (Leopold, 1933), birds (Gates \& Gysel, 1978) and spiders (Horváth et al., 2002). Forest edges, however, might have negative effects, particularly with respect to forest-inhabiting species, which avoid edges or have low abundance in these habitats (Lidicker, 1999).

The carabid beetles are particularly sensitive to habitat edges at the assemblage and species level (Kotze \& Samways, 2001; Magura, 2002; Koivula et al., 2004; Taboada et al., 2004). Moreover, previous studies of edge effects have shown versatile responses at the assemblage level and several species-specific responses (e.g. Heliölä et al., 2001; Kotze \& Samways, 2001; Molnár et al., 2001; Magura, 2002; Taboada et al., 2004; Yu et al., 2010). Carabid beetle species richness and diversity are significantly higher in forest edges than in the forest interior of oak forests in Hungary (Molnár et al., 2001; Magura, 2002) and beech forests in Romania (Máthé, 2006), while significant difference in these parameters were not observed in Afromontan forests in Africa (Kotze \& Samways, 2001) and oak and pine forests in China (Yu et al., 2010). Edge effects can be detected using life-history traits of carabids, especially those associated with a species affinity for a particular habitat (Koivula et al., 2004; Elek \& Tóthmérész, 2010). The flightless, large forest species showed enhanced use of forest edges (Koivula et al., 2004; Elek \& Tóthmérész, 2010) and some successfully penetrate into the open habitat matrix (Heliölä et al., 2001; Koivula et al., 2004). On the other hand, small and medium-sized open habitat species with high dispersal power are more sensitive to forest edges than forest species in Finland (Koivula et al., 2004). Previous studies on carabids in habitat edges were conducted mostly at abrupt forest edges (e.g. Heliölä et al., 2001; Koivula et al., 2004) and at successional forest edges (e.g. Molnár et al., 2001; Magura, 2002; Máthé, 2006), while there is no information on the responses of carabids to old embedded forest edges. These edges have a similar structure and density of vegetation to the forest interior and it is likely they buffer edge effects (e.g. Matlack, 1994; Denyer et al., 2006).

This study presents the results of edge effects on carabid beetle assemblages of old forest edges embedded in a forest continuum matrix in a Dinaric beech-fir forest. The aim was to describe the effect of forest edges in terms of a carabid response: (1) at the assemblage level and (2) at the life-history trait level. In addition, the effect of certain environmental variables (i.e. soil temperature and humidity, $\mathrm{pH}$, canopy cover, etc.) on the spatial distribution of carabids across these ecotones was determined. Forest species are expected to have higher activity density in the forest interior and the ecotone than in the meadow, while open habitat species are expected to occur only sporadically in the forest interior due to their ecological requirements. Macropterous and small and medium-sized species are expected to be more affected by the forest edge with their activity density declining from the ecotone towards the forest interior. However, the opposite pattern is expected for brachypterous and large carabid beetle species and hygrophilous and xerophilous species.

\section{MATERIAL AND METHODS}

\section{Study area and sampling design}

The study area is located near the Ravna Gora settlement in the Gorski Kotar region of western Croatia $\left(45^{\circ} 20^{\prime} 45^{\prime \prime} \mathrm{N}\right.$, $14^{\circ} 59^{\prime} 16^{\prime \prime} \mathrm{E}$ ) at an altitude of $945 \mathrm{~m}$. In this region, Dinaric beechfir forests [as. Omphalodo-Fagetum (Tregubov, 1957) Marinček et al., 1993] make up the most extensive forest vegetation. These forests grow in an area where limestone and dolomite are the parent rocks (Vukelić et al., 2008). The sampling area was located in three different habitats: in the forest interior, its forest edge and in an adjacent meadow. The forest interior (1) is characterized by a dense litter layer and well developed understory vegetation. The canopy and shrub layers are dominated by beech (Fagus sylvatica L.) and silver fir (Abies alba Mill.), though other species, including Norway spruce [Picea abies (L.) H. Karst.], sycamore (Acer pseudoplatanus L.) and European mountain ash (Sorbus aucuparia L.) occur frequently. In the herbaceous plant layer, blue-eyed Mary (Omphalodes verna Moench), wood anemone (Anemone nemorosa L.) and ramsons (Allium ursinum L.) are dominant. The forest edge (2) is more than 100 years old and characterized by tall trees and dense shrub and herbaceous layers. The plant species in the forest interior were also the dominant species at the forest edge. The adjacent area was a meadow (3) with a particularly diverse herbaceous plant flora and dense herbaceous plant layer. The vegetation belongs to the AlchemilloTrisetetum Horvat, 1962 and Festuco-Agrostetum Horvat, 1962 associations, which are in dynamic relation. The herbaceous plant layer is dominated by orchard grass (Dactylis glomerata L.), torgrass (Brachypodium pinnatum (L.) P. Beauv.), hedge bedstraw (Galium mollugo L.) and yarrow (Achillea millefolium L.).

A two-sided ecotone approach was applied as recommended by Fonseca \& Joner (2007) and ecotones were studied as gradients that extended $60 \mathrm{~m}$ from the forest edge into the forest interior and $60 \mathrm{~m}$ from the same edge into the meadow (Fig. 1) (sensu lato Meiners \& Pickett, 1999). In order to avoid an edge effect, a 60-m distance from the edge was used (Murcia, 1995). The first trap line was placed at the forest edge (distance $0 \mathrm{~m}$ ) between the meadow and the forest interior. Other trap lines ran parallel with the forest edge at different distances from the forest edge. Two study sites were selected (at least $1000 \mathrm{~m}$ apart), and each had nine trap lines. Pitfall traps (polyethylene cups $9.4 \mathrm{~cm}$ wide and $13.5 \mathrm{~cm}$ deep) were arranged in a trap line and each trap line consisted of 5 pitfall traps (at $5 \mathrm{~m}$ intervals). A total of 90 pitfall traps were set. The traps were partially filled with a solution of an equal 
60

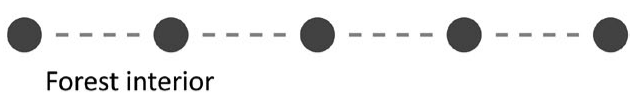

45

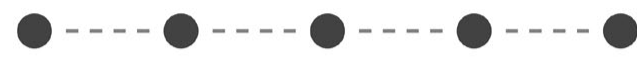

30

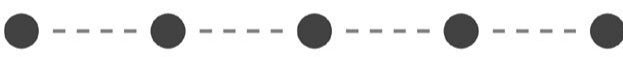

15

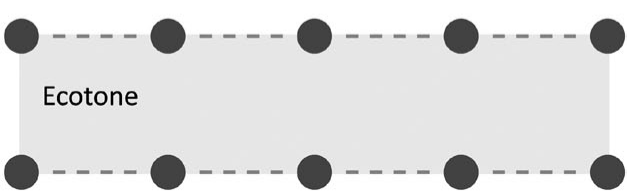

15

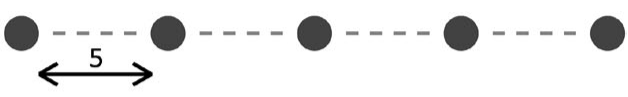

30

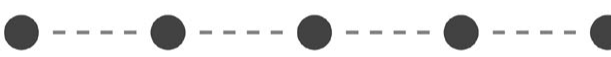

45

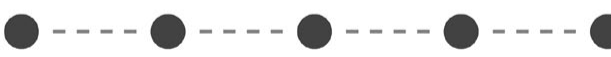

Meadow

60

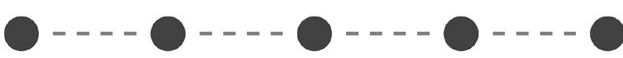

Fig. 1. The study site showing the main habitats and distance between trap lines in meters. Black circles represent pitfall traps.

volumes of wine-vinegar, $75 \%$ ethanol and water. To reduce the surface tension of the liquid, a drop of neutrally-smelling detergent was added. A dark roof was placed above each trap to protect the traps from rain and litter. Samples were collected monthly from April to late November 2009.

Carabid beetles were identified to species using Mlynář (1977), Turin et al. (2003) and Freude et al. (2006) and the nomenclature follows Löbl \& Smetana (2003). All voucher specimens are deposited in the first author's collection (Division of Biology, Faculty of Science, Zagreb). A life-history traits database (habitat preference, wing type, moisture preference and body size classes) was compiled for further analyses based on data in relevant literature (Lindroth, 1992; Hůrka, 1996; Turin et al., 2003; Freude et al., 2006; Luka et al., 2009) and our own field observations.

\section{Environmental variables}

Soil temperature was measured at a depth of $10 \mathrm{~cm}$ using a P300 Dostmann electronic thermometer. Soil humidity was measured at a depth of $15 \mathrm{~cm}$ using a FieldScout ${ }^{\mathrm{TM}}$ TDR 100/200 soil moisture meter. Soil temperature and humidity were measured at each site during every field survey. Soil $\mathrm{pH}$ was measured in the laboratory in water with a ratio of $1: 2.5(\mathrm{w} / \mathrm{v})(10 \mathrm{~g}$ substrate / $25 \mathrm{~mL} \mathrm{H}_{2} \mathrm{O}$ ) using a WTW pH 330i meter. Hemispherical photographs were taken with a fish-eye lens camera (Nikon Coolpix 8400, Nikon FC 9 Circulra Fisheye) in July 2009. At each site, 3 to 5 photographs were taken at a height $1.3 \mathrm{~m}$ above the ground (except in the meadow, where the height was $0.7 \mathrm{~m}$ ). Light intensity was calculated using WinScanopy Pro software (Regent, 2006).

\section{Data analysis}

Non-metric multidimensional scaling (NMDS) was applied to display and the test for dissimilarities in the composition of carabid species among the habitat-types using the Bray-Curtis index of dissimilarity for activity density data.

Diversity of the pooled samples for habitat types was compared using the Rényi one-parametric diversity index family. In the case of diversity indices, a family of diversity values was used to characterize the diversity of an assemblage instead of a single numerical value (Tóthmérész, 1995). These methods can be used in a graphical form to visualize the diversity relations of assemblages (Lövei, 2005). The one-parametric diversity indices may be portrayed graphically by plotting diversities against a scale parameter. Members of a one-parametric diversity index family have varying sensitivities to rare and abundant species as the scale parameter changes (Tóthmérész, 1998). The Rényi diversity is a typical member of generalized entropy functions (Ricotta, 2005), which includes the number of species, Shannon diversity, Simpson or quadratic diversity and the dominance index as a special case (Tóthmérész, 1998). When the value of the scale parameter is zero, the Rényi diversity is extremely sensitive to the contribution of rare species to the diversity of the assemblage. When the value of the scale parameter approaches one, then the Rényi diversity is identical to the Shannon diversity and is sensitive to rare species, although less so than at zero. When the value of the scale parameter is two, the Rényi diversity is related to quadratic (Simpson) diversity. In this case, the index is slightly more sensitive to frequent than to rare species. When the value of the scale parameter is large (approaches positive infinity), the Rényi diversity is related to the Berger-Parker dominance index that is determined only by the relative abundance of the most common species.

To measure habitat use by carabid beetles and the effectiveness of the sampling, rarefaction analyses were conducted. Species richness was estimated in each habitat type using the Chao estimator (Chao, 1987). Standard deviations were generated from 10,000 reshufflings of the sample order. These analyses were performed using R 3.0.1 software (R Core Team, 2013) using MASS (Venables \& Ripley, 2002) and Vegan packages (Oksanen et al., 2013).

In order to compare total activity density and life history trait categories, one-way ANOVA or Kruskal-Wallis H tests were used, followed by post hoc Unequal N HSD or Multiple comparison tests. The $\mathrm{p}$-values are expressed with the Bonferroni correction. The selection of parametric or non-parametric tests depended on the normality of the data, which was tested using a ShapiroWilk $\mathrm{W}$ test. For this analysis carabid beetle activity density data were pooled for each site sampled, i.e. the catches in five traps in a line at each distance from the forest edge $(0,15,30,45$ and $60 \mathrm{~m}$ ) recorded over the whole trapping period. The same tests were applied to detect differences in the environmental variables measured in the three habitats. Mean seasonal values of environmental variables (i.e. soil temperature, humidity) were calculated for each site sampled and used in the analyses. These tests were performed using Statistica 10.0 software (StatSoft Inc.).

The relationship between carabid beetle assemblages and environmental variables was tested using Canonical Correspondence Analysis (CCA) and the CANOCO version 4.5 package (ter Braak \& Smilauer, 2002). Down weighting of rare carabid species was performed and all species with lower than $0.05 \%$ abundance at each site studied were excluded from the analysis. Therefore, 36 species were included in the analysis. Prior to the analysis, carabid beetle activity densities were square transformed. A Monte Carlo test using 199 permutations $(p<0.05)$ was performed to test the significance of the correlations between species occur- 


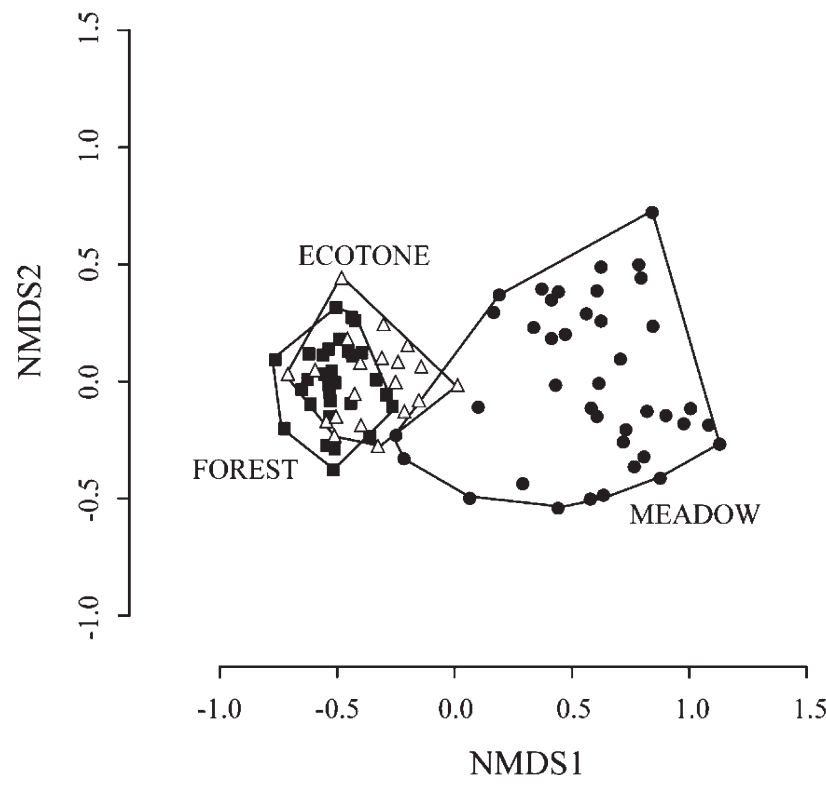

Fig. 2. Ordination of non-metric multidimensional scaling based on the Bray-Curtis dissimilarity index and activity density of carabids; the stress of the two dimensional configuration was 9.7.

rence and environmental variables. Only the significant variables were included in the model (ter Braak \& Verdonschot, 1995).

\section{RESULTS}

\section{Environmental variables}

Mean soil temperature [Kruskal-Wallis test $\mathrm{H}(2, \mathrm{~N}=54)$ $=31.732, \mathrm{p}<0.001]$ was significantly higher in the meadow than the forest interior $(\mathrm{p}<0.001)$ and the ecotone $(\mathrm{p}<0.01)$ (Table 1), with no significant difference between that recorded in the forest interior and the ecotone $(p>0.05)$. Mean soil humidity was lower in the forest interior $(\mathrm{p}<0.001)$ and the ecotone $(\mathrm{p}<0.001)$ compared to the meadow [Kruskal-Wallis test $\mathrm{H}(2, \mathrm{~N}=54)=39.685$, $\mathrm{p}<0.001]$. However, there was no significant difference in this respect between the forest interior and the ecotone $(\mathrm{p}>0.05)$. Mean soil $\mathrm{pH}$ values $( \pm \mathrm{SD})$ were $5.9 \pm 0.8$ in the forest interior, $5.5 \pm 0.6$ in the ecotone and $5.9 \pm 0.5$ in the meadow. The sites studied did not differ significantly in mean soil $\mathrm{pH}$ (one-way ANOVA; d.f. $=2,15$, $\mathrm{F}=0.641, \mathrm{p}>0.05)$. Mean light intensity differed significantly between sites studied [Kruskal-Wallis test $\mathrm{H}$ (2, $\mathrm{N}=54)=39.562, \mathrm{p}<0.001]$. The multiple comparison post

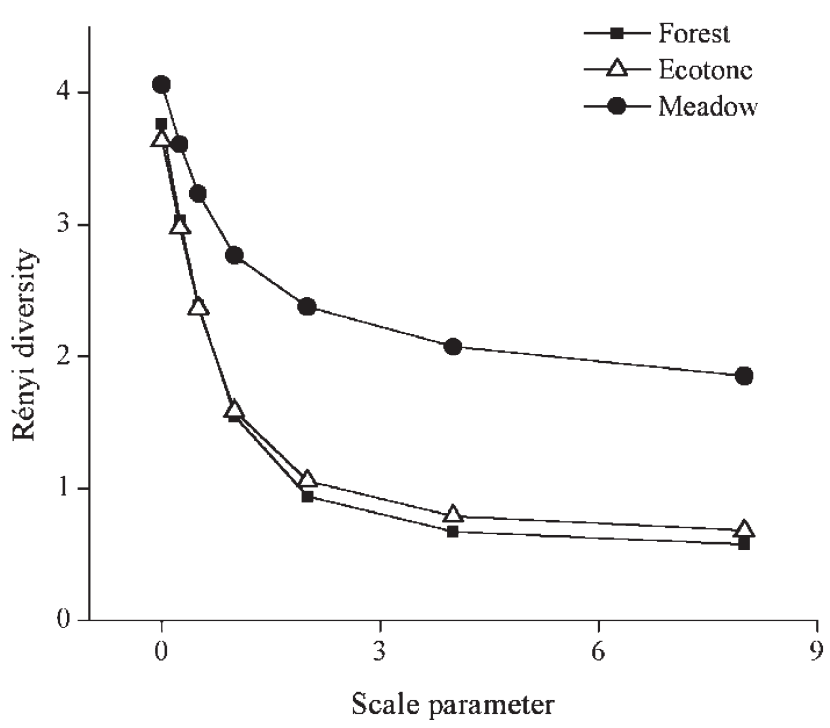

Fig. 3. Diversity profiles of the carabid assemblages in the habitat studied, based on the Rényi one-parametric diversity index family.

hoc test revealed that mean light intensity was significantly higher in the meadow than the ecotone $(\mathrm{p}<0.001)$ and the forest interior $(p<0.001)$, with no significant difference in that recorded for the ecotone and the forest interior $(\mathrm{p}>0.05)$.

\section{Assemblage description}

In total 20,526 carabid beetles belonging to 66 species were captured (Appendix 1). Nebria dahlii was the most abundant species, with 9948 specimens (48.47\% of the total catch). Other dominant species were Abax ovalis (2428 individuals), Aptinus bombarda (2098 individuals) and Pterostichus burmeisteri (1594 individuals) (Appendix 1). Together these species made up $78.24 \%$ of the total catch and occurred in all three habitats. In addition, Molops striolatus, Poecilus cupreus and Bembidion lampros were the dominant species in meadows. With the exception of two rare species, Notiophilus quadripunctatus and Trechus amplicollis, none of the other species caught were restricted to the ecotone zone (Appendix 1).

\section{Edge effect on carabid beetle assemblages}

The results of non-metric multidimensional scaling revealed that the site cores (i.e. beetle assemblages based on the trap catches) in the ecotone grouped together with

TABLE 1. Soil properties of the habitats studied in the Gorski Kotar region, Western Croatia.

\begin{tabular}{|c|c|c|c|c|c|c|c|}
\hline Environmental variables \& habitats & May & June & July & August & September & October & November \\
\hline FOREST INTERIOR & & & & & & & \\
\hline Soil temperature $\left({ }^{\circ} \mathrm{C}\right)(10 \mathrm{~cm}$; mean $\pm \mathrm{SD})$ & $9.27 \pm 0.47$ & $11.09 \pm 0.73$ & $13.32 \pm 0.80$ & 14.29 & 11.47 & $5.9 \pm 0.68$ & $4.02 \pm 0.66$ \\
\hline $\begin{array}{l}\text { Soil humidity }(\%)(\text { mean } \pm \text { SD }) \\
\text { EсотONE }\end{array}$ & $41.52 \pm 8.26$ & $39.2 \pm 11.89$ & $34.75 \pm 12.08$ & $27.23 \pm 6.30$ & $38.46 \pm 8.44$ & $44.04 \pm 10.06$ & 48.6 \\
\hline Soil temperature $\left({ }^{\circ} \mathrm{C}\right)(10 \mathrm{~cm}$; mean $\pm \mathrm{SD})$ & $9.38 \pm 0.39$ & $11.57 \pm 0.68$ & $13.69 \pm 1.17$ & $14.33 \pm 0.44$ & $12.08 \pm 0.33$ & $6.07 \pm 0.77$ & $3.9 \pm 0.76$ \\
\hline $\begin{array}{l}\text { Soil humidity }(\%)(\text { mean } \pm \text { SD) } \\
\text { MEADOW }\end{array}$ & $40.71 \pm 7.23$ & $39.43 \pm 7.83$ & $43.83 \pm 5.94$ & $32.8 \pm 7.08$ & $36.78 \pm 8.32$ & $46.2 \pm 8.13$ & $52.94 \pm 7.17$ \\
\hline Soil temperature $\left({ }^{\circ} \mathrm{C}\right)(10 \mathrm{~cm}$; mean $\pm \mathrm{SD})$ & $10.83 \pm 0.98$ & $13.68 \pm 1.44$ & $14.7 \pm 0.88$ & $14.63 \pm 0.55$ & $13.58 \pm 0.61$ & $6.13 \pm 1.13$ & $2.88 \pm 1.22$ \\
\hline Soil humidity (\%) (mean $\pm \mathrm{SD})$ & $43.9 \pm 6.66$ & $41.64 \pm 7.07$ & $44.16 \pm 4.66$ & $34.76 \pm 5.77$ & $40.09 \pm 7.68$ & $56.45 \pm 7.39$ & $59.18 \pm 11.70$ \\
\hline
\end{tabular}



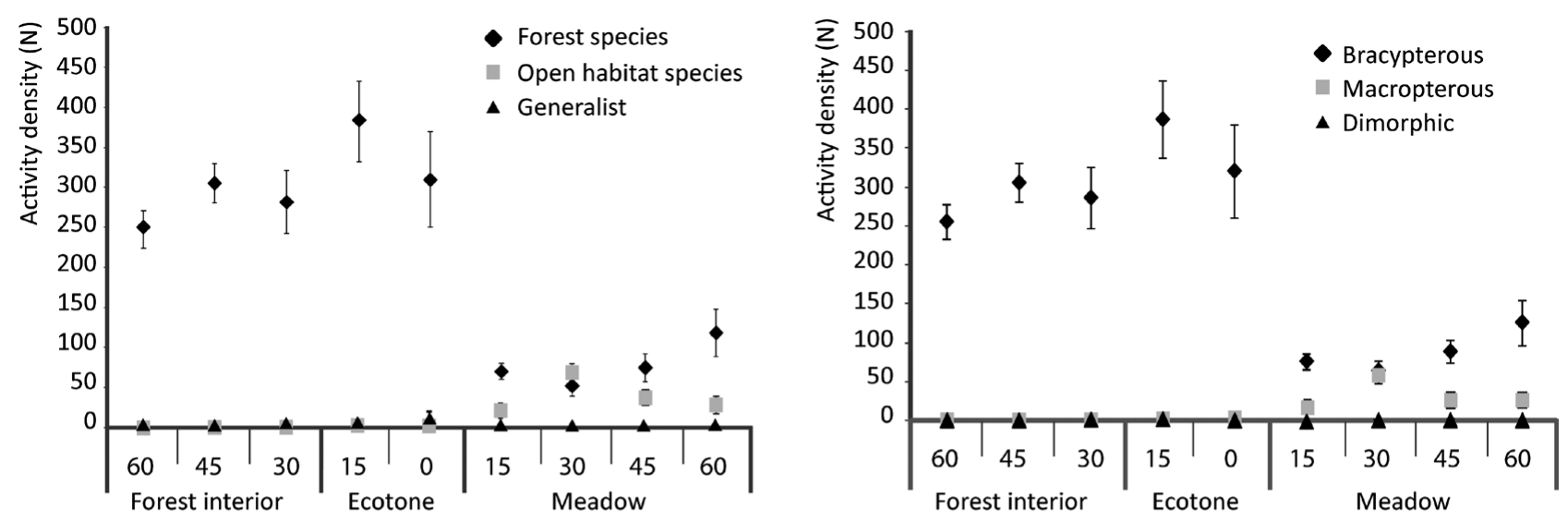

A)

B)
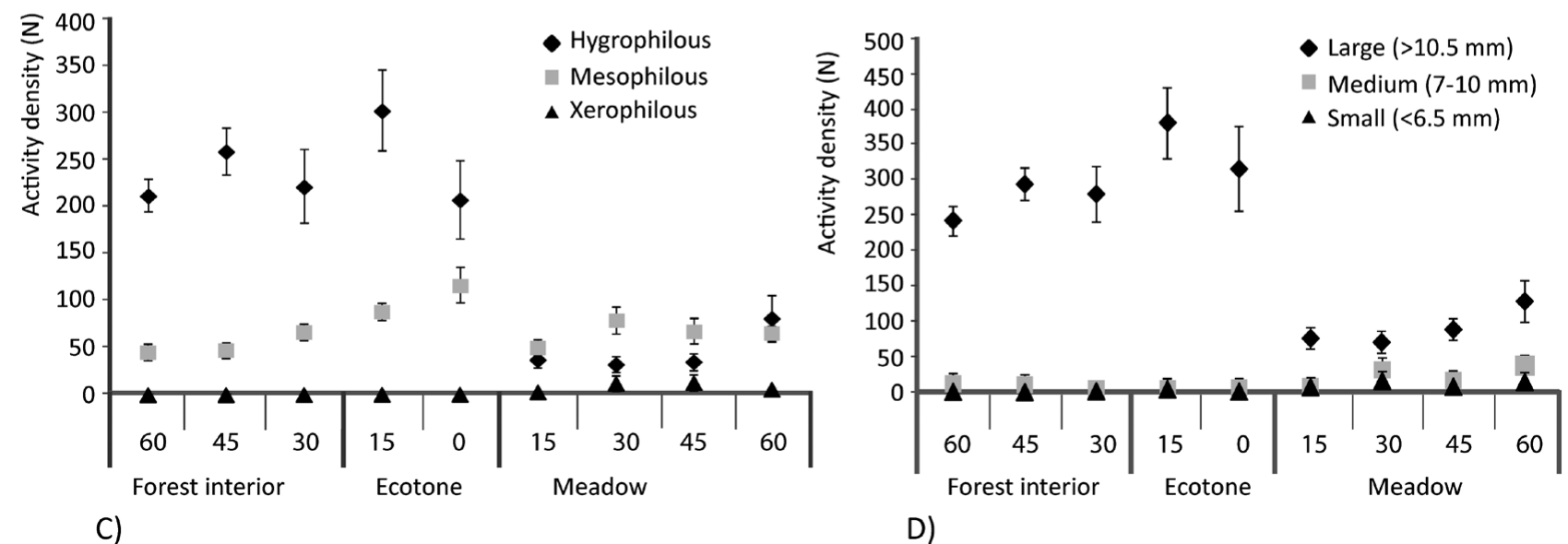

Fig. 4. Analysis of life history traits of the carabids and their mean activity density (per trap \pm SE). Life history database and classification criteria are presented in Appendix 1.

those similarly recorded for the forest interior, while those recorded in the meadow was clearly separated from the previous two (Fig. 2). This indicates that carabid beetle assemblages in the ecotone were more similar to assemblages in the forest interior than those in the meadow.
Rényi diversity profiles revealed that the meadow was the most diverse habitat (Fig. 3). The total number of species caught was identical in the forest interior and the ecotone and highest in the meadow. On the other hand, the ecotone was less diverse in terms of the dominant species

TABLE 2. Comparisons of different types of habitats using a Kruskal-Wallis rank sum test and the activity density data per life history trait category. The P values were adjusted by Bonferroni corrections. Abbreviations: F - forest interior; E - ecotone; M - meadow.

\begin{tabular}{|c|c|c|c|c|c|}
\hline \multirow{2}{*}{ Life-history traits } & \multicolumn{3}{|c|}{ Mean of the ranks } & \multirow{2}{*}{ Kruskal-Wallis } & \multirow{2}{*}{ Comparisons $(\mathrm{p}<0.05)$} \\
\hline & Forest interior & Ecotone & Meadow & & \\
\hline \multicolumn{6}{|l|}{ HABITAT PREFERENCE } \\
\hline Forest spp. & 60.68 & 68.4 & 22.66 & 56.07 & $\mathrm{~F}=\mathrm{E}>\mathrm{M}$ \\
\hline Open-habitat spp. & 19.42 & 35.42 & 70.1 & 70.03 & $\mathrm{M}>\mathrm{E}>\mathrm{F}$ \\
\hline $\begin{array}{l}\text { Generalist spp. } \\
\text { WING TYPE }\end{array}$ & 48.5 & 69.58 & 31.21 & 29.68 & $\mathrm{E}>\mathrm{F}>\mathrm{M}$ \\
\hline Brachypterous spp. & 60.62 & 68.68 & 22.58 & 56.58 & $\mathrm{~F}=\mathrm{E}>\mathrm{M}$ \\
\hline Dimorphic spp. & 43.27 & 53.7 & 48.08 & 4.01 & $\mathrm{E}=\mathrm{F}=\mathrm{M}$ \\
\hline $\begin{array}{l}\text { Macropterous spp. } \\
\text { MoISTURE PREFERENCE }\end{array}$ & 20.02 & 35.65 & 67.4 & 55.83 & $\mathrm{M}>\mathrm{E}>\mathrm{F}$ \\
\hline Hygrophilous spp. & 63.12 & 65.3 & 22.39 & 56.45 & $\mathrm{~F}=\mathrm{E}>\mathrm{M}$ \\
\hline Mesophilous spp. & 34.52 & 66.47 & 43.25 & 18.49 & $\mathrm{E}>\mathrm{F}=\mathrm{M}$ \\
\hline $\begin{array}{l}\text { Xerophilous spp. } \\
\text { BODY SIZE CLASSES }\end{array}$ & 27.45 & 32.78 & 65.4 & 52.4 & $\mathrm{M}>\mathrm{F}=\mathrm{E}$ \\
\hline Large (> $10 \mathrm{~mm})$ & 60.38 & 68.32 & 22.92 & 54.88 & $\mathrm{~F}=\mathrm{E}>\mathrm{M}$ \\
\hline Medium (7-10 mm) & 41.2 & 30.05 & 56.45 & 14.88 & $\mathrm{M}>\mathrm{F}=\mathrm{E}$ \\
\hline Small $(<6.9 \mathrm{~mm})$ & 25.98 & 37.62 & 64.8 & 39.31 & $\mathrm{M}>\mathrm{F}=\mathrm{E}$ \\
\hline
\end{tabular}




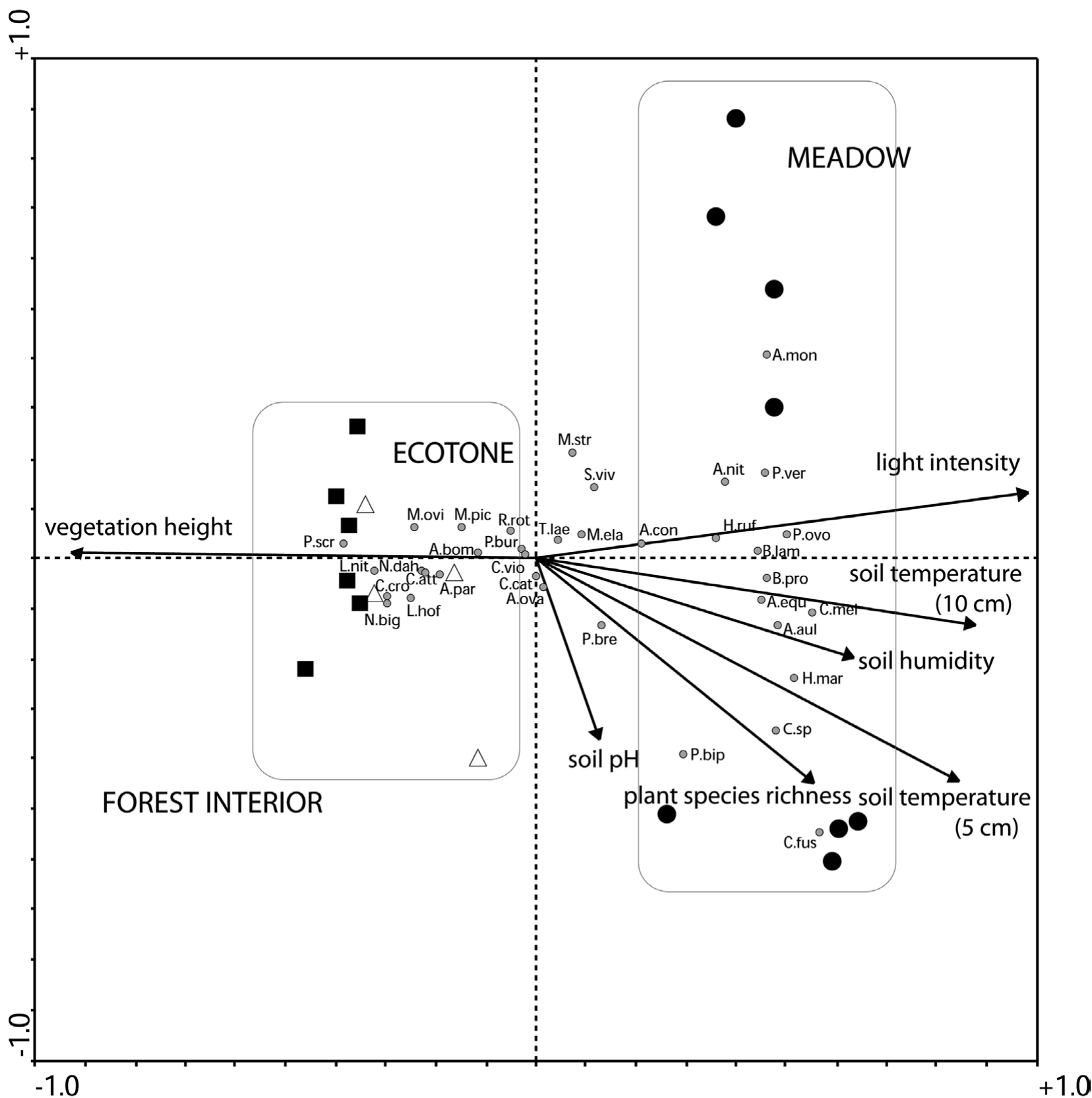

Fig. 5. CCA analysis of carabid beetles and environmental variables. Carabid species are marked with grey circles and environmental variables with arrows. Abbreviations for the carabid species are listed in Appendix 1. Forest interior habitats are indicated by black squares, and those of ecotones by white triangles and meadows by black circles.

than the meadow and those recorded in the forest were the least diverse.

The estimates of species richness were not stable for any of the habitats, but increased continuously with increase in the number of samples. The estimated species richness $($ mean \pm SD) was highest in the meadow $(52.67 \pm 2.03$ for 20 samples), while the ecotone (39 species for 20 samples) and forest $(34.27 \pm 1.37$ for 20 samples) were similar in species richness.

High activity density of carabids was recorded in both the ecotone (mean per trap \pm SE: $358.1 \pm 38.78$ ) and the forest interior $(283.97 \pm 51.84)$, but was rather low in the meadow (121.15 \pm 9.91$)$. Activity density differed significantly between the sites studied (one-way ANOVA; d.f. $=2,15, F=23.309, p<0.001)$. Based on the results of the Unequal N HSD post hoc test, activity density was significantly higher in the forest interior $(p<0.01)$ and the ecotone $(p<0.001)$ than in the meadow. However, there was no significant difference in activity density recorded in the forest interior and the ecotone $(\mathrm{p}>0.05)$.

Analysis of life history traits (summarized in Table 2, Fig. 4) revealed that forest species prevailed in the forest interior and the ecotone, while their activity density was significantly less in the meadow. In contrast, open habitat species were dominant in the meadow, whereas their activity density was significantly less in the ecotone and the forest interior (Fig. 4). Generalist species were more abundant in the ecotone than in the other habitats. Brachypter- 
ous species were more abundant in the forest interior and the ecotone than in the meadow, whereas the opposite pattern was detected for macropterous species. Hygrophilous species were more abundant in the forest interior and the ecotone than in the meadow, but mesophilous species were more abundant in the ecotone than in the forest interior or the meadow. Xerophilous species were associated with the meadow. Large carabids prevailed in the forest interior and the ecotone than the meadow, while medium- and smallsized species were more abundant in the meadow than in the ecotone or the forest interior, but the activity density recorded in the latter two habitats did not differ.

\section{Carabid beetle assemblages and environmental variables}

In the CCA, the first two axes explained $65.7 \%$ of the variance in carabid beetle occurrence in the habitats studied and $84.3 \%$ of the variance in the relationship between environmental variables and carabid beetle species. The first two axes had eigenvalues of 0.369 and 0.068 . Monte Carlo randomization test (199 permutations) revealed that the ordination was statistically significant $(\mathrm{F}=5.022$, $\mathrm{p}=0.005)$. The first axis of the ordination indicated an obvious separation between the meadow habitat (right side) and the forest interior and ecotone habitats, which are positioned close together (axis 1, Fig. 5). The meadow sites are positioned both above and below the $\mathrm{x}$ axis and in figure 5 they appear to be mutually distant. However, since the second eigenvalue is much smaller than the first, their position should be measured in terms of their distance from the $\mathrm{x}$ axis, and in that case they are more similar. Most of the environmental variables measured (light intensity, soil temperature, soil moisture, plant species richness) are associated with the first CCA axis and those for the meadow occur in this part of the ordination diagram. Light intensity had the longest vector and highest correlation with the first axis $(r=0.96)$. The direction of the height of the vegetation vector is opposite to that for the other environmental variables and associated with forest interior and ecotone habitats. Forest specialists, such as Platynus scrobiculatus, Carabus croaticus and Nebria dahlii, are located on the left side of the ordination near the forest interior and ecotone sites. Forest generalists, such as Abax ovalis and Pterostichus burmeisteri, are placed in the centre of the ordination. In contrast, open habitat species, such as Amara nitida, Calathus fuscipes, Harpalus marginellus, Poecilus versicolor and Pterostichus ovoideus are grouped on the right side of the ordination near the meadow sites.

\section{DISCUSSION}

The present study revealed that (1) carabid beetle assemblages in the ecotone were more similar to those in the forest interior than in the meadow; (2) the life-history traits appeared to be a more appropriate tool for detecting an edge effect than broad estimators such as total species richness and activity density; (3) old forest edges are barriers to the movement of open habitat species, but act as filters for some forest species and (4) the main environmental variables did not differ significantly between forest interior and ecotone, providing stable microclimatic conditions for forest species to move to the forest edge.

\section{Carabid beetle responses to ecotones}

NMDS and CCA analyses clearly revealed that carabid beetle assemblages in the ecotone were more similar to those in the forest interior than to those in the meadow. These results are in accordance with results of other studies conducted at both successional (Magura et al., 2001; Molnár et al., 2001; Magura, 2002) and abrupt forest edges (Heliölä et al., 2001). Microclimatic conditions were similar in the forest interior and the ecotone, which is associated with a very similar structure and composition of vegetation in these two habitats. The present study and others have shown that embedded forest edges may buffer or mitigate microclimate edge effects (e.g. Matlack, 1993; Denyer et al., 2006). These conditions possibly enable forest carabids to maintain stable populations in the ecotone. In addition, the great resemblance of the assemblages recorded in the forest interior and the forest edge is similar to that recorded in successional forest edges for other invertebrate taxa, such as spiders (Horváth et al., 2002) and various beetle families (Yu et al., 2006).

The Rényi diversity index and rarefied species richness were higher for the meadow than the ecotone and the forest interior, which is not in accordance with the classical edge effect hypothesis (Clements, 1905). A similar pattern is recorded in other studies worldwide, such as beech forest edges in Hungary (Elek \& Tóthmérész, 2010), boreal forest edges in Finland (Heliölä et al., 2001), Afromontan forest edges in South Africa (Kotze \& Samways, 2001) and deciduous forest edges in China (Yu et al., 2007). However, other studies indicate that species richness and diversity is higher in edge habitats, e.g. in oak-hornbeam forest edges in Hungary (Molnár et al., 2001; Magura, 2002) and beech forest edges in Romania (Máthé, 2006). It is likely that these different responses of carabid assemblages could be determined by geographical differences, or variation in forest edge features (e.g. edge type, age and physiognomy); while the adjacent matrix of habitats may play a crucial role in determining the responses of the selected indicator taxa. Thus, the responses of carabid assemblages to edge effects are likely to be context dependent. The recorded pattern in diversity (i.e. meadow as the most diverse habitat) could be a consequence of the greater evenness in the meadow resulting in a high activity density and moderate species richness. A similar pattern in species richness and activity density is described for spiders by Liu et al. (2004).

In the present study, the total activity density of carabids was significantly higher in the forest interior and the ecotone than the meadow. In both cases, this is mainly due to the high activity density of the four dominant species (Nebria dahlii, Abax ovalis, Pterostichus burmeisteri and Aptinus bombarda). Uniform microclimates in homogeneous beech forests support there few cold-preferring carabid species with a high activity density (Thiele, 1977) similar to that recorded in this study. In addition, Starčević (2013) reports a high abundance of shrews (Sorex Linneaus, 1758) in the same ecotone, which could have resulted from the 
high activity density of carabids recorded there. A similar pattern in carabid activity density is reported along grassland-oak-hornbeam forest transects (Magura, 2002; Magura et al., 2002) and between grassland-edge-beech forest habitats (Elek \& Tóthmérész, 2010).

The forest interior and ecotone habitats were found to be affected by the height of the vegetation, which indirectly affects the stability of the microclimate (e.g. coefficients of variation of measured abiotic factors were low in the forest interior and the ecotone). Forest specialists (such as Carabus croaticus, Platynus scrobiculatus, Pterostichus variolatus and Nebria dahlii) prefer the lower temperatures, moist soils and shaded habitats that occur in the forest interior and ecotone. Light intensity and soil temperature had a significant effect on the carabid assemblages in the meadow, with open-habitat species such as, Amara equestris, A. nitida, A. aulica, Calathus fuscipes, Poecilus versicolor and Harpalus rufipes, associated with the meadow habitats. These species prefer higher temperatures and moderately moist to dry soils (Thiele, 1977; Lindroth, 1992; Hůrka, 1996).

\section{Life-history traits and ecotones}

This study revealed asymmetric responses in the ecotone in terms of activity density in several life-history traits, such as habit affinity (forest associated species vs. openhabitat species), flight ability (brachypterous vs. macropterous) and body size (medium vs. large-sized). That is forest associated species were less affected by the ecotone than the open-habitat species. Moreover, they either maintained stable populations in the ecotone or passed through the ecotone into the meadow. For example, some forest specialists, such as Nebria dahlii maintained stable populations in the ecotone, which supports the results of Spence et al. (1996) who showed that some forest specialists may exhibit high activity density in the clear-cut edges of forests. In addition, several forest generalists such as Abax ovalis, Molops elatus, M. striolatus and Pterostichus burmeisteri passed through the ecotone and maintained stable populations in the meadow, possibly because of the dense herbaceous plant layer and surprisingly high soil humidity in the meadow. The significantly higher soil humidity in the meadow could be associated with soil depth and texture. The soil in the meadow was deeper and less rocky than the soil in the ecotone or the forest interior.

Open-habitat species were more sensitive to the ecotone than the forest associated species. Although they are mainly macropterous and have good flight and dispersal abilities (den Boer, 1990), they rarely occurred in the forest interior. Similarly, Heliölä et al. (2001), Koivula et al. (2004) and Yu et al. (2007) report that open-habitat species are scarce in the forest interiors, but more abundant in adjacent open habitats. In this study, the embedded forest edges were formed more than 100 years ago and the meadows maintained for grazing and cutting (Šporer, pers. com.). These edges are characterized by a high tree layer and extremely dense shrub and herbaceous plant layers, which might act as a physical barrier for open-habitat species. Furthermore, Dinaric beech-fir forests are cold, shaded and humid, and the microclimatic conditions are unsuitable for these heliophilous species (Thiele, 1977). A similar asymmetric pattern between forest and open-habitat species is reported in forest-farmland edges in Finland (Koivula et al., 2004). In addition, Skłodowski (2004) reports that open-habitat species might immigrate into the forest interior and contribute to the overall biodiversity, though their density is extremely low in a large forest continuum matrix.

Brachypterous and large-sized species were more abundant in the forest interior and their activity density significantly lower in the meadow. Flight ability is connected with the stability of the environment (den Boer, 1990) and brachypterous species prefer large, continuous and stable forest habitats (Brandmayr, 1983). Oscillations in temperature, humidity and wind are less pronounced in the interior of Dinaric beech-fir forests than in open habitats, and can affect the spatial distribution of carabid beetle species. The activity density of macropterous and medium-sized carabids was considerably less in the forest interior than in the meadow, mainly due the presence there of several open-habitat species of the genus Amara (Thiele, 1977). The high numbers of large carabids in the meadow was unexpected, but is attributed to forest generalists that successfully passed through the ecotone and maintained stable populations in the meadow (e.g. Abax ovalis, Molops striolatus and Pterostichus burmeisteri).

\section{CONCLUSIONS}

This study revealed that carabid beetle assemblages in the ecotone are mainly composed of species from the forest interior and some from the meadow. Therefore, forest species were not negatively affected by embedded forest edges. Moreover, activity density of some forest species was high in the ecotone, which is most likely due to the higher habitat stability in the ecotone, since the embedded forest edge eliminated the microclimate edge effect. In addition, for some forest species the embedded forest edges act as filters, while for open habitat species they represent true barriers (Kolasa \& Zalewski, 1995). Some of the open habitat species, such as Amara curta, A. montivaga, A. nitida and Trichotichnus laevicollis, are regionally rare species (Novak, 1952; Durbešić, 1982; Bregović, 1985) and endangered in Croatia (Vujčić-Karlo et al., 2007). Moreover, areas of open habitat are subject to colonization by forest plants, such as Norway spruce ( $P$. abies), when traditional management practices cease (Topić \& Vukelić, 2009). These meadows have great conservation value not only for carabids but also for plants (Topić \& Nikolić, 2005) and butterflies (Mihoci et al., 2006).

The microclimate edge effect of embedded forest edge was reduced due to the similarity of the structure and composition of the vegetation in the forest interior and the ecotone. Such features of edges may have an application in the forest management, in particular in the creation of forest edges. Planting of herbaceous plants and young trees at abrupt forest edges could diminish the microclimate edge effect and create a more stable environment for forest invertebrates, in particular carabid beetles. Such manage- 
ment practices could be especially beneficial in fragmented forest landscapes.

ACKNOWLEDGEMENTS. We would like to thank S. Križanić, D. Križanić and D. Brigić for their help with field work. Many thanks to S. Mikac (Faculty of Forestry, University of Zagreb, Croatia) for assistance in taking hemispherical photographs and to A. Alegro, R. Šoštarić and V. Šegota for the phytosociological relevés of vegetation. We wish to thank the staff of the Ravna Gora Forest Management unit for their hospitality during field work. Additionally, we would like to thank S. Vujčić Karlo for her comments on the manuscript and A. Previšić and L. Zanella for improving the English.

\section{REFERENCES}

ANDRÉN H. 1992: Corvid density and nest predation in relation to forest fragmentation: a landscape perspective. - Ecology $\mathbf{7 3}$ 794-804.

Boncina A. 2011: History, current status and future prospects of uneven-aged forest management in the Dinaric region: an overview. - Forestry 84: 467-477.

BRANDMAYR P. 1983: The main axes of the coenoclinal continuum from macroptery to brachyptery in carabid communities of the temperate zone. In Brandmayr P., den Boer P.J. \& Weber F. (eds): Ecology of Carabids: The Synthesis of Field Dtudy and Laboratory Experiment. University of Münster, Westphalia, pp. 147-169.

BREgović A. 1985: Carabid beetle collection of Entomological Department of Varaždin City Museum. - GGMV 7: 221-248 [in Croatian].

Cadenasso M.L., Pickett S.T.A., Weathers K.C. \& Jones C.G. 2003: A framework for a theory of ecological boundaries. BioScience 53: 750-758.

CHАо A. 1987: Estimating the population size for capture-recapture data with unequal catchability. - Biometrics 43: 783-791.

Clements F.E. 1905: Research Methods in Ecology. University Publishing Company, Lincoln, 362 pp.

DEN BoER P.J. 1990: Density limits and survival of local populations in 64 carabid species with different powers of dispersal. - J. Evol. Biol. 3: 19-48.

Denyer K., Burns B. \& Ogden J. 2006: Buffering of native forest edge microclimate by adjoining tree plantations. - Austral Ecol. 31: 478-489.

Durbešı́c P. 1982: Carabid Beetle Fauna (Coleoptera) of Forest Communities in the Gorski Kotar Region. Doctoral thesis, Faculty of Science, University of Zagreb, Zagreb, 252 pp. [in Croatian].

Elek Z. \& Tóthmérész B. 2010: Carabid beetles among grassland - forest edge - beech forest habitats in Northern Hungary. Commun. Ecol. 11: 211-216.

EwERs R.M. \& DidHAM R.K. 2006: Continuous response functions for quantifying the strength of edge effects. - J. Appl. Ecol. 43: 527-536.

FonseCa C.R. \& JonER F. 2007: Two-sided edge effect studies and the restoration of endangered ecosystems. - Restor. Ecol. 15: 613-619.

Forman R.T.T. \& Moore P.N. 1992: Theoretical foundations for understanding boundaries in landscape mosaics. In Hansen A.J. $\&$ di Castri F. (eds): Landscape Boundaries: Consequences for Biotic Diversity and Ecological Flows. Ecological studies 92, Springer, New York, pp. 236-258.

Gates J.E. \& Gysel L.W. 1978: Avian nest dispersion and fledging success in field-forest ecotones. - Ecology 59: 871-883.

Gosz J.R. 1991: Fundamental ecological characteristics of landscape boundaries. In Holland M.M., Naiman R.J. \& Risser P.G. (eds): Role of Landscape Boundaries in the Management and Restoration of Changing Environments. Chapman and Hall, New York, pp. 8-30.

Heliölä J., Koivula M. \& Niemelä J. 2001: Distribution of carabid beetles (Coleoptera, Carabidae) across a boreal forestclearcut ecotone. - Conserv. Biol. 15: 370-377.

Holland M.M. 1988: SCOPE/MAB Technical consultations on landscape boundaries; report of a SCOP/MAB workshop on ecotones. - Biol. Internat. (spec. issue) 17: 47-106.

Horvat I., Glavač V. \& Ellenberg H. 1974: Vegetations Südosteuropas. G. Fischer, Sttutgart, 768 pp.

Horváth R., Magura T., Péter G. \& Tóthmérész B. 2002: Edge effect on weevils and spiders. - Web Ecol. 3: 43-47.

HƯRKA K. 1996: Carabidae of the Czech and Slovak Republics. Kabourek, Zlín, 565 pp.

Kapos V., Wandelli E., Camargo J.L. \& Ganade G. 1997: Edgerelated changes in environment and plant responses due to forest fragmentation in central Amazonia. In Laurance W.F. \& Bierregaard R.O. Jr (eds): Tropical Forest Remnants. The University of Chicago Press, Chicago, pp. 33-44.

KlePAC D. 2001: The development of fir forest management. In Prpić B. (ed.): Silver Fir in Croatia. Academy of Forestry Science, Zagreb, pp. 65-89.

Koivula M.J., Hyyrylainen V. \& Soininen E. 2004: Carabid beetles (Coleoptera, Carabidae) at forest-farmland edges in southern Finland. - J. Insect Conserv. 8: 297-309.

Kolasa J. \& Zalewski M. 1995: Notes on ecotone attributes and functions. - Hydrobiologia 303: 1-7.

Kotze D.J. \& Samways M.J. 2001: Invertebrate conservation at the interface between the grassland matrix and natural Afromontane forest fragments. - Biodivers. Conserv. 8: 1339-1363.

LAHTI D.C. 2001: The "edge effect on nest predation" hypothesis after twenty years. - Biol. Conserv. 99: 365-374.

Laurance W.F., Nascimento H.E.M., Laurance S.G., Andrade A., Ewers R.M., Harms K.E., Luiza R.C.C. \& Ribeiro J.E. 2007: Habitat fragmentation, variable edge effects, and the landscape-divergence hypothesis. - PLoS ONE 2(10): e1017.

Leopold A. 1933: Game Management. Charles Scribner's Sons, New York, $481 \mathrm{pp}$.

LIDICKER W.Z. JR 1999: Responses of mammals to habitat edges: an overview. - Landsc. Ecol. 14: 333-433.

Lindenmayer D.B. \& Fischer J. 2006: Habitat Fragmentation and Landscape Change, an Ecological and Conservation Synthesis. Island Press, Washington D.C., 328 pp.

Lindroth C.H. 1992: Ground Beetles (Carabidae) of Fennoscandia: A Zoogeographic Study. Specific Knowledge Regarding the Species. Part 1. Smithsonian Institution Libraries and The National Science Foundation, Washington D.C., 630 pp.

Liu W.-X., Wan F.-H., Guo J.-Y. \& Lövei G.L. 2004: Spiders and their seasonal dynamics in transgenic Bt vs. conventionally managed cotton fields in north-central China. In Samu F. \& Szinetár Cs. (eds): European Arachnology 2002. Proceedings of the 20th European Colloquium of Arachnology. Plant Protection Institute \& Berzsenyi College, Budapest, pp. 337-342.

LöVEI G. 2005: Generalised entropy indices have a long history in ecology - a comment. - Commun. Ecol. 6: 245-247.

Luka H., Marggi W., Huber C., Gonseth Y. \& Nagel P. 2009: Coleoptera, Carabidae: Ecology, Atlas. Fauna Helvetica 24. Centre Suisse de Cartographie de la Faune \& Schweizerische Entomologische Gesellschaft, Neuchâtel, 677 pp.

MaguRA T. 2002: Carabids and forest edge: spatial pattern and edge effect. - Forest Ecol. Manag. 157: 23-37.

Magura T., Tóthmérész B. \& Bordán Zs. 2002: Carabids in an oak-hornbeam forest: Testing the edge effect hypothesis. Acta Biol. Debrec. 24: 55-72. 
MÁthé I. 2006: Forest edge and carabid diversity in a Carpathian beech forest. - Commun. Ecol. 7: 91-97.

MATLACK G.R. 1993: Microclimate variation within and among forest edge sites in the Eastern United States. - Biol. Conserv. 66: $185-194$.

MatLACK G.R. 1994: Vegetation dynamics of the forest edgetrends in space and successional time. - J. Ecol. 82: 113-123.

MeIners S.J. \& Pickett S.T.A. 1999: Changes in community and population responses across a forest-field gradient. - Ecography 22: 261-267.

Minoci I., VAJdić M. \& ŠAšIĆ M. 2006: The status of the Damon Blue Polyommatus (Agrodiaetus) damon (Denis \& Schiffermüller, 1775) (Papilionoidea: Lycaenidae, Polyommatini) in the Croatian butterfly fauna. - Nat. Croat. 15: 15-25.

MLYNÁr̆ Z. 1977: Revision der Arten und Unterarten der Gattung Molops Bon. (s. str.) (Coleoptera, Carabidae). - Folia Entomol. Hung. 30: 3-150.

Molnár T., Magura T., Tóthmérész B. \& Elek Z. 2001: Ground beetles (Carabidae) and edge effect in oak-hornbeam forest and grassland transects. - Eur. J. Soil Biol. 37: 297-300.

MurCiA C. 1995: Edge effects in fragmented forests: implications for conservation. - Trends Ecol. Evol. 10: 58-62.

NovaK P. 1952: Beetles (Coleoptera) of Croatian Costal Region. JAZU, Zagreb, 521 pp. [in Croatian].

Oksanen J., Blanchet F.G., Kindt R., Legendre P., O’Hara R.B., Simpson G.L., Solymos P., Stevens M.H.M. \& Wagner H. 2013: vegan: Community Ecology Package. R package version 2.0-7. Online at http://CRAN.R-project.org/package=vegan

PARDINI R. 2004: Effects of forest fragmentation on small mammals in an Atlantic Forest landscape. - Biodivers. Conserv. 13: $2567-2586$.

R Core Team 2013: R: A language and Environment for Statistical Computing. R Foundation for Statistical Computing, Vienna, Austria. URL http://www.R-project.org/.

REgENT 2006: WinSCANOPY for Hemispherical Image Analysis Manual. Regent Instruments Inc., Chemin Sainte-Foy, Quebec.

RicotTA C. 2005: On parametric diversity indices in ecology: A historical note. - Commun. Ecol. 6: 241-244.

Ries L., Fletcher R.J. JR, Battin J. \& SisK T.D. 2004: Ecological responses to habitat edges: mechanisms, models, and variability explained. - Annu. Rev. Ecol. Evol. 35: 491-522.

Risser P.G. 1995: The status of the science examining ecotones. - BioScience 45: 318-325.

Robinson S.K., Thompson F.R., Donovan T.M., Whitehead D.R. \& FAABROG J. 1995: Regional forest fragmentation and the nesting success of migratory birds. - Science 267: 1987-1990.

RUCNER Z. 1994: Beitrag zur Entomofauna einiger Waldassoziationen Kroatiens. - Nat. Croat. 3: 1-22.

Saunders D.A., Hobbs R.J. \& Margules C.R. 1991: Biological consequences of ecosystem fragmentation: a review. - Conserv. Biol. 5: 18-32.

SkŁodowski J.J.W. 2004: The occurrence of carabids in yellow plates in the Bialowieza Primeval Forest. - Baltic J. Coleopterol. 4: 117-123.

Spence J.R., Langor D.W., Niemelä J., Carcamo H.A. \& Currie C.R. 1996: Northern forestry and carabids: the case for concern about old-growth species. - Ann. Zool. Fenn. 33: 173-184.

StarČEvić M. 2013: Effect of Forest Edge on Small Mammals Community. Master thesis, Faculty of Science, University of Zagreb, 60 pp. [in Croatian].

Statsoft Inc. 2010: Statistica (Date Analysis Software System), Version 10. http://www.statsoft.com/
Štrbenac A., Huber Đ., Kusak J., Oković P., Sindičić M., Jeremić J., Frković A. \& Gomerčić T. 2008: Conservation of Large Carnivores in Croatia. State Institute for Nature Protection, Zagreb, 40 pp. [in Croatian].

Taboada A., Kotze D.J. \& Salgado J.M. 2004: Carabid beetle occurrence at the edges of oak and beech forests in NW Spain. - Eur. J. Entomol. 101: 555-563.

TER BRAak C.J.F. \& Smilauer P. 2002: CANOCO Reference Manual and CanoDraw for Windows User's Guide: Software for Canonical Community Ordination (Version 4.5). Microcomputer Power, Ithaca, NY, USA.

TER BRAAK C.J.F. \& VERDONSCHOT P.F.M. 1995: Canonical correspondence analysis and related multivariate methods in aquatic ecology. - Aquat. Sci. 57: 255-289.

Thiele H.U. 1977: Carabid Beetles in their Environments. Springer, Berlin, 369 pp.

Topić J. \& NiKolić T. 2005: Analysis of threats to Croatian flora. In Nikolić T. \& Topić J. (eds): Red Book of Vascular Flora of Croatia. Ministry of Culture \& State Institute for Nature Protection, Zagreb, pp. 587-600.

Topić J. \& VuKelić J. 2009: Interpretation Manual of Habitats Classification According to the EU Habitats Directive. State Institute for Nature Protection, Zagreb, 376 pp. [in Croatian].

Tóтнме́RÉsz B. 1995: Comparison of different methods for diversity ordering. - J. Veg. Sci. 6: 283-290.

TótHмÉRÉsz B. 1998: On the characterization of scale-dependent diversity. - Abstr. Bot. 22: 149-156.

Turin H., Penev I. \& Casale A. 2003: The Genus Carabus in Europe. Pensoft, Sofia-Moscow, $511 \mathrm{pp}$

Venables W.N. \& Ripley B.D. 2002: Modern Applied Statistics with $S$. Springer, Berlin, 501 pp.

Vujčić-KARLo S. 1999: Faunistic and Ecological Studies of Carabid Beetles in Different Forest Communities in Croatia. Doctoral thesis, Faculty of Science, University of Zagreb, $256 \mathrm{pp}$. [in Croatian].

Vujčić-Karlo S., Brigić A., Šerić Jelaska L., Kokan B. \& Hrašovec B. 2007: Red List of Threatened Carabid Beetles in Croatia. State Institute for Nature Protection, Zagreb (http:// www.dzzp.hr/publikacije/crveni popis trchci.pdf).

Vukelić J. 2012: Forest Communities in Croatia. Faculty of Forestry \& State Institute for Nature Protection, Zagreb, 398 pp.

Vukelić J., Mikac S., Baričević D., Bakšić D. \& Posavec R. 2008: Forest Habitats and Forest Communities in Croatia, National Ecological Network. State Institute for Nature Protection, Zagreb, $263 \mathrm{pp}$.

WATLING J.I. \& ORROCK J.L. 2010: Measuring edge contrast using biotic criteria helps define edge effects on the density of an invasive plant. - Landsc. Ecol. 25: 69-78.

Yu X.-D., Luo T.-H., YANG J. \& Zhou H.-Z. 2006: Distribution of ground-dwelling beetles (Coleoptera) across a forest-clearcut ecotone in Wolong Natural Reserve, southwestern China. Insect Sci. 13: 127-135.

Yu X.-D., Luo T.-H., Zhоu H.-Z. \& YANG J. 2007: Distribution of carabid beetles (Coleoptera: Carabidae) across a forest-grassland ecotone in southwestern China. - Environ. Entomol. 36: 348-355.

Yu X.-D., Luo T.-H. \& Zноu H.-Z. 2010: Distribution of grounddwelling beetle assemblages (Coleoptera) across ecotones between natural oak forests and mature pine plantations in North China. - J. Insect Conserv. 14: 617-626.

Received December 20, 2013; revised and accepted September 18, 2014 Prepublished online October 10, 2014 
ApPENDIX 1. Carabid beetle species recorded in this study. Species traits based on the literature (see text) and authors' data: Habitat preference (F forest species, $\mathrm{G}$ - generalists, $\mathrm{O}$ - open habitat species); Humidity preference ( $\mathrm{H}$ - hygrophilous, $\mathrm{M}$ - mesophilous, $\mathrm{X}$ - xerophilous); Flight ability (B - brachypterous species, unable to fly, D - wing-dimorphic species, L - macropterous species, able to fly); Body size categories (L - large $>10$ mm, $\mathrm{M}$ - medium 7-10 mm, S - small $<6.9 \mathrm{~mm}$ ). Abbreviation: $\%$ - share in the assemblage.

\begin{tabular}{|c|c|c|c|c|c|c|c|c|c|c|}
\hline \multirow[b]{2}{*}{ Species name } & \multicolumn{5}{|c|}{ Life-history traits } & \multicolumn{5}{|c|}{ Activity density } \\
\hline & Abbrev. & $\begin{array}{l}\text { Habitat } \\
\text { prefer. }\end{array}$ & $\begin{array}{c}\text { Humidity } \\
\text { prefer. }\end{array}$ & $\begin{array}{l}\text { Flight } \\
\text { ability }\end{array}$ & $\begin{array}{c}\text { Body size } \\
\text { categories/ } \\
\mathrm{mm}\end{array}$ & $\begin{array}{l}\text { Forest } \\
\text { interior }\end{array}$ & $\begin{array}{l}\text { Eco- } \\
\text { tone }\end{array}$ & Meadow & Total & $\%$ \\
\hline Abax carinatus Duftschmid, 1812 & A.car & $\mathrm{F}$ & M & $\mathrm{B}$ & $\mathrm{L}$ & 1 & & 2 & 3 & 0.015 \\
\hline Abax ovalis Duftschmid, 1812 & A.ova & $\mathrm{F}$ & $\mathrm{H}$ & $\mathrm{B}$ & $\mathrm{L}$ & 683 & 787 & 958 & 2428 & 11.829 \\
\hline Abax parallelepipedus Piller \& Mitterpacher, 1783 & A.par & $\mathrm{F}$ & M & $\mathrm{B}$ & $\mathrm{L}$ & 41 & 25 & 6 & 72 & 0.351 \\
\hline Agonum sexpunctatum Linné, 1758 & A.sex & $\mathrm{O}$ & M & M & $\bar{M}$ & & & 2 & 2 & 0.010 \\
\hline Amara aenea DeGeer, 1774 & A.aen & $\mathrm{O}$ & $\mathrm{X}$ & M & M & & & 2 & 2 & 0.010 \\
\hline Amara aulica Panzer, 1796 & A.aul & $\mathrm{O}$ & M & M & $\mathrm{L}$ & & 1 & 155 & 156 & 0.760 \\
\hline Amara communis Panzer, 1797 & A.com & $\mathrm{O}$ & M & M & $\mathrm{M}$ & 1 & & 3 & 4 & 0.019 \\
\hline Amara convexior Stephens, 1828 & A.con & $\mathrm{O}$ & M & M & M & 1 & 4 & 13 & 18 & 0.088 \\
\hline Amara curta Dejean, 1828 & A.cur & $\mathrm{O}$ & M & M & M & & & 2 & 2 & 0.010 \\
\hline Amara equestris Duftschmid, 1812 & A.equ & $\mathrm{O}$ & $\mathrm{X}$ & M & $\mathrm{L}$ & 1 & 3 & 81 & 85 & 0.414 \\
\hline Amara famelica C. Zimmermann, 1832 & A.fam & $\mathrm{O}$ & M & M & $\mathrm{M}$ & & & 1 & 1 & 0.005 \\
\hline Amara lunicollis Schiødte, 1837 & A.lun & $\mathrm{O}$ & M & M & M & & & 2 & 2 & 0.010 \\
\hline Amara montivaga Sturm, 1825 & A.mon & $\mathrm{O}$ & $\mathrm{X}$ & M & M & & & 33 & 33 & 0.161 \\
\hline Amara nitida Sturm, 1825 & A.nit & $\mathrm{O}$ & M & M & M & 2 & 4 & 148 & 154 & 0.750 \\
\hline Amara ovata Fabricius, 1792 & A.ova & $\mathrm{O}$ & M & M & M & & & 2 & 2 & 0.010 \\
\hline Aptinus bombarda Illiger, 1800 & A.bom & $\mathrm{F}$ & M & $\mathrm{B}$ & $\mathrm{L}$ & 599 & 1142 & 348 & 2089 & 10.177 \\
\hline Bembidion lampros Herbst, 1784 & B.lam & $\mathrm{O}$ & M & M & $\mathrm{S}$ & 3 & 3 & 198 & 204 & 0.994 \\
\hline Bembidion properans Stephens, 1828 & B.pro & $\mathrm{O}$ & $\mathrm{H}$ & M & $\mathrm{S}$ & & 1 & 38 & 39 & 0.190 \\
\hline Calathus fuscipes Goeze, 1777 & C.fus & $\mathrm{O}$ & M & $\mathrm{B}$ & $\mathrm{L}$ & & & 14 & 14 & 0.068 \\
\hline Calathus sp. & C.sp & & & $\mathrm{B}$ & $\mathrm{L}$ & & 2 & 171 & 173 & 0.843 \\
\hline Calathus melanocephalus Linné, 1758 & C.mel & $\mathrm{O}$ & $\mathrm{X}$ & $\mathrm{B}$ & M & & & 36 & 36 & 0.175 \\
\hline Carabus catenulatus Scopoli, 1763 & C.cat & $\mathrm{G}$ & M & $\mathrm{B}$ & $\mathrm{L}$ & 13 & 22 & 14 & 49 & 0.239 \\
\hline Carabus convexus Fabricius, 1775 & C.con & G & M & $\mathrm{B}$ & $\mathrm{L}$ & & & 1 & 1 & 0.005 \\
\hline Carabus coriaceus Linné, 1758 & C.cro & $\mathrm{F}$ & M & $\mathrm{B}$ & $\mathrm{L}$ & 57 & 17 & 4 & 78 & 0.380 \\
\hline Carabus irregularis Fabricius, 1792 & C.irr & $\mathrm{F}$ & $\mathrm{H}$ & $\mathrm{B}$ & $\mathrm{L}$ & 1 & 1 & & 2 & 0.010 \\
\hline Carabus violaceus Dejean, 1826 & C.vio & G & M & $\mathrm{B}$ & $\mathrm{L}$ & 59 & 118 & 72 & 249 & 1.213 \\
\hline Cychrus attenuatus Fabricius, 1792 & C.att & $\mathrm{F}$ & $\mathrm{H}$ & $\mathrm{B}$ & $\mathrm{L}$ & 276 & 108 & 22 & 406 & 1.978 \\
\hline Harpalus atratus Latreille, 1804 & H.atr & $\mathrm{G}$ & M & $\mathrm{D}$ & $\mathrm{L}$ & & & 1 & 1 & 0.005 \\
\hline Harpalus laevipes Zetterstedt, 1828 & H.lae & $\mathrm{G}$ & M & M & $\mathrm{L}$ & & & 1 & 1 & 0.005 \\
\hline Harpalus latus Linné, 1758 & H.lat & $\mathrm{G}$ & M & M & M & 1 & & 6 & 7 & 0.034 \\
\hline Harpalus luteicornis Duftschmid, 1812 & H.lut & $\mathrm{O}$ & M & M & $\mathrm{S}$ & & & 2 & 2 & 0.010 \\
\hline Harpalus marginellus Gyllenhal, 1827 & H.mar & $\mathrm{O}$ & M & $\mathrm{M}$ & $\mathrm{L}$ & & & 56 & 56 & 0.273 \\
\hline Harpalus rufipes DeGerr, 1774 & H.ruf & $\mathrm{O}$ & M & M & $\mathrm{L}$ & 2 & 1 & 30 & 33 & 0.161 \\
\hline Lebia chlorocephala J.J. Hoffmann, 1803 & L.chl & $\mathrm{O}$ & $\mathrm{X}$ & M & $\mathrm{S}$ & & & 2 & 2 & 0.010 \\
\hline Leistus nitidus Duftschmid, 1812 & L.nit & G & $\mathrm{H}$ & $\mathrm{B}$ & M & 48 & 22 & 1 & 71 & 0.346 \\
\hline Leistus piceus Frölich, 1799 & L.pic & $\mathrm{F}$ & $\mathrm{H}$ & $\mathrm{B}$ & M & 19 & 15 & & 34 & 0.166 \\
\hline Licinus hoffmannseggii Panzer, 1803 & L.hof & $\mathrm{G}$ & $\mathrm{H}$ & $\mathrm{B}$ & M & 28 & 25 & 3 & 56 & 0.273 \\
\hline Molops elatus Fabricius, 1801 & M.ela & $\mathrm{F}$ & $\mathrm{H}$ & $\mathrm{B}$ & $\mathrm{L}$ & 60 & 56 & 167 & 283 & 1.379 \\
\hline Molops ovipennis Chaudoir, 1847 & M.ovi & $\mathrm{F}$ & M & $\mathrm{B}$ & $\mathrm{L}$ & 61 & 10 & 5 & 76 & 0.370 \\
\hline Molops piceus Ganglbauer, 1889 & M.pic & $\mathrm{F}$ & $\mathrm{H}$ & $\mathrm{B}$ & $\mathrm{L}$ & 81 & 48 & 21 & 150 & 0.731 \\
\hline Molops striolatus Fabricius, 1801 & M.str & $\mathrm{F}$ & M & $\mathrm{B}$ & $\mathrm{L}$ & 108 & 185 & 533 & 826 & 4.024 \\
\hline Nebria dahlii Duftschmid, 1812 & N.dah & $\mathrm{F}$ & $\mathrm{H}$ & $\mathrm{B}$ & $\mathrm{L}$ & 5513 & 3957 & 478 & 9948 & 48.465 \\
\hline Notiophilus biguttatus Fabricius, 1779 & N.big & $\mathrm{F}$ & $\mathrm{H}$ & $\mathrm{D}$ & $\mathrm{S}$ & 11 & 18 & & 29 & 0.141 \\
\hline Notiophilus palustris Duftschmid, 1812 & N.pal & $\mathrm{F}$ & $\mathrm{H}$ & $\mathrm{D}$ & $\mathrm{S}$ & 1 & & 3 & 4 & 0.019 \\
\hline Notiophilus quadripunctatus Dejean, 1826 & N.qua & $\mathrm{F}$ & $\mathrm{H}$ & $\mathrm{D}$ & $\mathrm{S}$ & & 1 & & 1 & 0.005 \\
\hline Ophonus puncticeps Stephens, 1828 & O.pun & $\mathrm{O}$ & $\mathrm{X}$ & M & M & & & 2 & 2 & 0.010 \\
\hline Panagaeus bipustulatus Fabricius, 1775 & P.bip & $\mathrm{O}$ & $\mathrm{X}$ & M & M & & 2 & 6 & 8 & 0.039 \\
\hline Paradromius linearis Olivier, 1795 & P.lin & $\mathrm{G}$ & M & $\mathrm{D}$ & $\mathrm{S}$ & & & 1 & 1 & 0.005 \\
\hline Platynus scrobiculatus Fabricius, 1801 & P.scr & $\mathrm{F}$ & $\mathrm{H}$ & $\mathrm{B}$ & M & 163 & 9 & & 172 & 0.838 \\
\hline Poecilus lepidus Leske, 1785 & P.lep & $\mathrm{O}$ & $\mathrm{X}$ & $\mathrm{D}$ & $\mathrm{L}$ & & & 3 & 3 & 0.015 \\
\hline Poecilus versicolor Sturm, 1824 & P.ver & $\mathrm{O}$ & M & M & M & 2 & & 433 & 435 & 2.119 \\
\hline Pterostichus brevis Duftschmid, 1812 & P.bre & $\mathrm{F}$ & $\mathrm{H}$ & $\mathrm{B}$ & M & 23 & 29 & 68 & 120 & 0.585 \\
\hline Pterostichus burmeisteri Heer, 1838 & P.bur & $\mathrm{F}$ & M & $\mathrm{B}$ & $\mathrm{L}$ & 601 & 474 & 519 & 1594 & 7.766 \\
\hline Pterostichus ovoideus Sturm, 1824 & P.ovo & $\mathrm{O}$ & $\mathrm{H}$ & $\mathrm{B}$ & $\mathrm{S}$ & & & 101 & 101 & 0.492 \\
\hline Pterostichus strenuus Panzer, 1796 & P.str & $\mathrm{G}$ & $\mathrm{H}$ & M & $\mathrm{S}$ & & & 5 & 5 & 0.024 \\
\hline Pterostichus subsinuatus Dejean, 1828 & P.sub & $\mathrm{F}$ & M & $\mathrm{B}$ & $\mathrm{S}$ & & 1 & 2 & 3 & 0.015 \\
\hline Pterostichus variolatus Ganglbauer, 1891 & P.var & $\mathrm{F}$ & M & $\mathrm{B}$ & $\mathrm{L}$ & 17 & 8 & & 25 & 0.122 \\
\hline Pterostichus vernalis Panzer, 1796 & P.ver & G & M & M & $\mathrm{S}$ & & & 5 & 5 & 0.024 \\
\hline Reicheiodes rotundipennis Chaudoir, 1843 & R.rot & $\mathrm{F}$ & $\mathrm{H}$ & $\mathrm{B}$ & $\mathrm{S}$ & 13 & 8 & 12 & 33 & 0.161 \\
\hline Stomis rostratus Duftschmid, 1812 & S.ros & $\mathrm{F}$ & M & $\mathrm{B}$ & M & 7 & 4 & & 11 & 0.054 \\
\hline Syntomus obscuroguttatus Duftschmid, 1812 & S.obs & $\mathrm{G}$ & $\mathrm{X}$ & $\mathrm{M}$ & $\mathrm{S}$ & & & 1 & 1 & 0.005 \\
\hline Syntomus truncatellus Linné, 1761 & S.tru & $\mathrm{O}$ & M & $\mathrm{D}$ & $\mathrm{S}$ & & & 4 & 4 & 0.019 \\
\hline Synuchus vivalis Illiger, 1798 & S.viv & $\mathrm{O}$ & M & M & $\mathrm{S}$ & 4 & 23 & 34 & 61 & 0.297 \\
\hline Trechus amplicollis Fairmaire, 1859 & T.amp & $\mathrm{G}$ & $\mathrm{H}$ & $\mathrm{B}$ & $\mathrm{S}$ & & 1 & & 1 & 0.005 \\
\hline Trechus croaticus Dejean, 1831 & T.cro & $\mathrm{F}$ & M & $\mathrm{B}$ & $\mathrm{S}$ & 13 & 10 & 3 & 26 & 0.127 \\
\hline Trichotichnus laevicollis Duftschmid, 1812 & T.lae & $\mathrm{F}$ & $\mathrm{H}$ & M & M & 5 & 16 & 10 & 31 & 0.151 \\
\hline Species richness $(\mathrm{S})$ & & & & & & 36 & 38 & 58 & 66 & \\
\hline Activity density (N) & & & & & & 8519 & 7161 & 4846 & 20526 & \\
\hline
\end{tabular}

